C. Gómez-Bellver, E. Laguna, A. Agut, G. Ballester, S. Cardero, V. Deltoro, E. Fàbregas, S. Fos, S. Francisco, D. Guillot, J. E. Oltra, D. Pérez-Prieto, P. Pérez Rovira, R. Senar, N. Ibáñez, S. Herrando-Moraira, N. Nualart \& J. López-Pujol

\title{
The recent neophyte Opuntia aurantiaca (Cactaceae): distribution and potential invasion in the Iberian Peninsula
}

\begin{abstract}
Gómez-Bellver, C., Laguna, E., Agut, A., Ballester, G., Cardero, S., Deltoro, V., Fàbregas, E., Fos, S., Francisco, S., Guillot, D., Oltra, J. E., Pérez-Prieto, D., Pérez Rovira, P., Senar, R., Ibáñez, N., Herrando-Moraira, S., Nualart, N. \& López-Pujol, J.: The recent neophyte Opuntia aurantiaca (Cactaceae): distribution and potential invasion in the Iberian Peninsula. - Fl. Medit. 30: 377-390. 2020. — ISSN: 1120-4052 printed, 2240-4538 online.

The Cactaceae, and especially its most emblematic genus, Opuntia, is one of the groups of plants with greater invasion potential in the Iberian Peninsula. One of the most recently detected species is Opuntia aurantiaca, a small cactus with an enormous capacity of dispersion. Probably native to Argentina and Uruguay, it behaves as a very aggressive invader in Australia and South Africa. In Europe, it only occurs on the Mediterranean coast of the Iberian Peninsula (Catalonia and Valencian Community). In this study, the geographic range of the species is accurately delineated at the peninsular level. Detected firstly at the beginning of the last decade in Navajas (Castelló Province), it has been subsequently observed in other places of Castelló, but also in Valencia, Tarragona and Barcelona, and since 2017 in Girona. With all gathered occurrence data, the potential distribution of $O$. aurantiaca is estimated (for the current climatic conditions as well as for different scenarios of global warming). Despite the fact that the species seems to be spreading, maps of potential distribution do not forecast large expansions to other areas of the Iberian Peninsula, both for the present and for the year 2070.
\end{abstract}

Key words: alien flora, niche modelling, Spain.

\section{Introduction}

Although nearly all cacti (Cactaceae) are originally restricted to the New World, many species have become naturalized outside the Americas after having been introduced by man, for instance in Australia, South Africa, Hawaii, and the Mediterranean basin (Verloove \& Guiggi 2019). The introduction in these regions was due to their value as ornamental or industrial plants. Initially brought from the Americas by European explorers, probably at early-middle 16th century (Ochoa \& Barbera 2017), they soon became common in European collections and gardens (Anderson 2001; Novoa \& al. 2015). Since 
the 19th century, some of these species rapidly became a major weed problem (e.g. Walters \& al. 2011; Chinnock 2015; Novoa \& al. 2015). Among cacti, the genus Opuntia L., together with Cylindropuntia (Engelm.) F. M. Knuth, is the most problematic, having ca. 25 species reported as invasive (Novoa \& al. 2015).

The date of the first observation of many of the Opuntia spp. and other Cactaceae now present in the Iberian Peninsula is, however, very recent. According to Sanz-Elorza \& al. (2004), the genus has not spread considerably due to the lack of suitable areas, with the notable exception of O. ficus-indica (L.) Mill. Indeed, in Flora Europaea (Moore 1968) only five currently recognized species were included, although it should be taken into account that this treatment is over 50 years old. However, in Flora iberica (Berthet 1990), albeit published much later, only seven species are recognized. In Catalonia, where at present up to 20 taxa of Opuntia are listed (Aymerich \& Sáez 2019), in the early 1990s this genus had only two representatives according to Casasayas (1989). Since the 2000s, the number of newly reported species in the Iberian Peninsula has grown exponentially. This remarkable increase in the number of occurrences during the last two decades, which has also been observed for another group of succulent plants (Agave; Burguera \& al. 2019), might be due to several reasons: (1) the increase of the number of botanists and naturalists interested in the study of the alien flora, with several research groups specialized on alien plants having appeared since late 1990s; apart from the pioneering work of Casasayas (1989), the first lists and catalogues of alien flora in the Iberian Peninsula did not appear until late 1990s/early 2000s (Sanz-Elorza \& al. 2001); (2) the enormous habitat fragmentation (especially in coastal areas) linked to the strong economic growth of the Portuguese and Spanish economies after their adhesion to the European Union in 1986; such processes often enhance the introduction of alien plants (Mack \& al. 2000); (3) the spread of coastal/suburban second-home settlements thanks to the Spanish real estate bubble of 1995-2008, being composed in most cases of detached and semi-detached villas with private gardens; it is estimated that nearly 2 million of this kind of houses were built during the period 1995-2006 (Pozueta 2015); and (4) the "boom" of xero-gardening in Spain (Aymerich \& Sáez 2019), which involved the planting of many succulent alien species [belonging to families including Agavaceae, Asphodelaceae (where now Aloe spp. are included), Cactaceae, and Crassulaceae] in domestic yards. Additionally, the increase of detections of new populations can be also linked to the more engaged regional policies to fight against biological invasions, establishing protocols for early alert and quick communication of new locations of the most dangerous and expansive alien species. In the case of the Valencian Community, the regional Decree 213/2009 (Generalitat Valenciana 2009) establishes a network of early warning to detect and combat the presence of the most aggressive species, whose introduction in natural areas is fully forbidden. This network allows to provide fine information for species identification, and quick communication protocols to a large network of collaborators (environmental keepers, conservation NGOs, etc.) aiding the regional Wildlife Service to fight against the expansion of invasive species.

Opuntia aurantiaca Lindl. is a small cactus with an enormous capacity for dispersion by means of cladodes and sterile fruits (which can produce sprouts) that detach very easily and adhere to animals, clothing or footwear, and vehicle wheels. Its strong spines can easily penetrate the skin or can stick into the wool or hair of animals (CABI 2020). Its origin is uncertain, but according to Arnold (1977) and van de Venter \& al. (1984) it would be a 
natural hybrid between $O$. discolor Britton \& Rose and O. salmiana Pfeiff. [= Salmonopuntia salmiana (Pfeiff.) P. V. Heath] originated in South America (Argentina and Uruguay). It was probably first transported to the United Kingdom in 1824 (Moran \& al. 1976), and from there it was introduced in Cape Town (South Africa), probably in the 1840s (Moran \& Annecke 1979). Used as a garden ornamental and as a barrier plant, it seems that it soon escaped, with eradication activities starting already in the late 19th century but without much success (as it infested ca. 800,000 ha in less than 60 years; Moran \& Zimmermann 1991). In Australia, although not much information exists on how and when it was introduced (it was first noted in New South Wales in 1883; DAWE 2020), it is also a very aggressive invader, being considered among the most noxious weeds (CABI 2020), with individual patches of over 1,600 ha (DAWE 2020); for example, in New South Wales alone about 200,000 ha were infested in 1988 (Hosking 2002). Opuntia aurantiaca has been declared as a "weed of National Significance" in Australia (DAWE 2020). In recent years it has also been listed as a noxious weed in other two countries of southern Africa (Botswana and Zimbabwe) and in the United States (Novoa \& al. 2019). This cactus, in addition to being potentially harmful to people and animals (cattle and dogs), has negative impacts on the local flora (due to its ability to cover the soil densely) and on the economy (because it reduces cultivation and grazing areas). Eradication actions developed against this plant include chemical, mechanical and/or biological control (see Moran \& Annecke 1979; Moran \& Zimmermann 1991; CABI 2020; DAWE 2020).

In Europe, its presence as a neophyte is only known from Spain (Iberian Peninsula), in Mediterranean coastal areas. This newcomer in the Spanish alien flora has recently been detected in few sites of Catalonia and Valencian Community, where it has established small populations (Guàrdia 2016; Vázquez \& Albiach 2016; Verloove \& Guiggi 2019; Guardiola \& Petit 2020). However, we believe that the species is spreading fast according to our field observations, personal communications, as well as the existence of several unpublished records (or at least not published in standard scientific sources such as articles or books). A proof that this cactus has already become a problem in Spain is the existence of some recent removal actions (e.g. in the Collserola Mountains in Barcelona a few years ago; in the Empordà Plain, in northern Catalonia, in 2019; in Borriol, Castelló Province, in 2015-2018; in El Puig de Santa Maria and Llíria, province of Valencia, in 2015-2019).

The aims of the present study were the following: (1) to delineate accurately the present geographic range of $O$. aurantiaca in the Iberian Peninsula, by gathering and validating all the occurrences, both published in standard publications and available from other sources; and (2) to predict the potential distribution of this species through ecological niche modelling (ENM), both under the present climatic conditions and according to different scenarios of climate change.

\section{Materials \& methods}

\section{The study species}

The typical forms of Opuntia aurantiaca are semiprostrate cacti of up to $0.6 \mathrm{~m}$ tall, with cladodes of 4-23 $\times 1-4 \mathrm{~cm}$, deep green to purplish, cylindrical to subcylindrical when mature, and readily detachable (Fig. 1). Areoles contain 2-7 barbed spines (1-4 mm long) with minute 

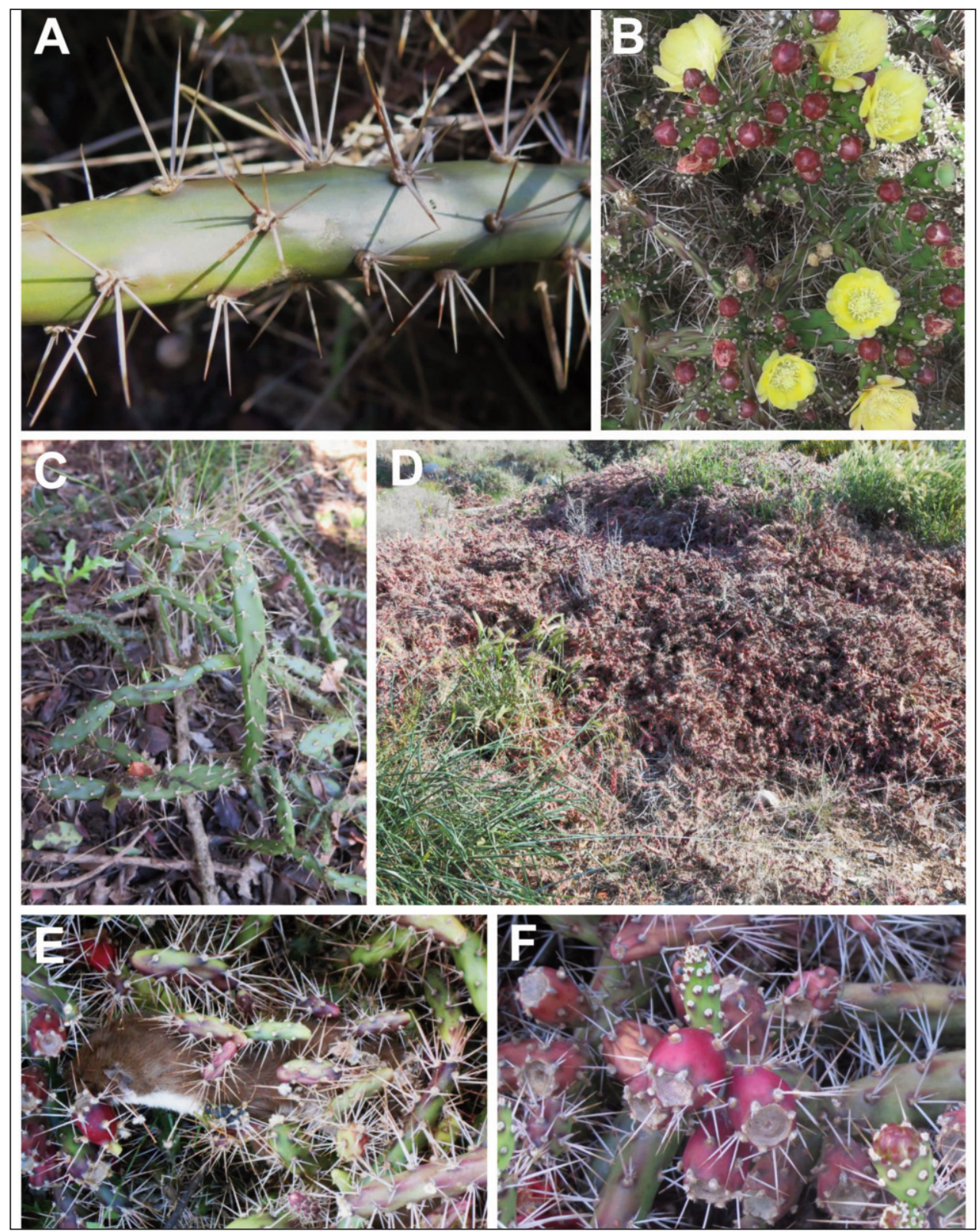

Fig. 1. Opuntia aurantiaca, growing in the wild in several locations of the Iberian Peninsula. (A), detail of the areoles and spines of a cladode, from Gavà (Barcelona, 2016); (B) flowering individual in Torreblanca (Castelló 2014), (C), individual from Gavà (Barcelona, 2016); (D), large infestation in Torreblanca (Castelló, 2015); (E), in the same population (Torreblanca, Castelló, 2015), a dead individual of least weasel (Mustela nivalis), probably because it was trapped among the spiny cladodes; (F), fruiting individual in Ulldecona (Tarragona, 2020). Photographs: (A) and (C), C. Gómez-Bellver; (B), P. San Lázaro; (D) and (E), P. Pérez Rovira; (F) S. Cardero. 
glochids and trichomes. The flowers are bright yellow, 2.5-6 cm wide, while the sterile, spiny fruits are about 2-3 cm long, pear-shaped, red-purple at maturity (van de Venter \& al. 1984; Guàrdia 2016; DAWE 2020). Although it has been reported that $O$. aurantiaca can produce apomictic seeds, these are rarely viable (Archibald 1939); therefore, it spreads mainly thanks to vegetative reproduction, mostly by cladode detachment; stem segments can be dispersed over long distances by animals, humans, vehicles, water or wind (Electronic Supplementary File 1, Fig. S1; Zimmermann \& van de Venter 1981; DAWE 2020). According to Moran \& Zimmermann (1991), a single individual produces a mean of ca. 170 cladodes. There are four morphotypes of this hybrid, the naturalized one being the typical form (morphotype A2, related to the O. discolor parent; Arnold 1977; van de Venter \& al. 1984). It is a tetraploid species with $2 n=4 x=44$ (Yuasa \& al. 1973). Plants are very long lived (DAWE 2020).

\section{Search for occurrences}

The distribution of Opuntia aurantiaca in the Iberian Peninsula has been updated and completed using different sources: (1) research articles; (2) global online databases as GBIF (GBIF 2020) or iNaturalist (www.inaturalist.org); (3) regional online databases as the Banco de Datos de Biodiversidad de la Comunidad Valenciana (www.bdb.gva.es); (4) grey literature (e.g. technical reports); and (5) herbarium specimens. In addition, an extensive field work has been carried out by the authors of this contribution.

\section{Ecological niche modelling}

The maximum entropy algorithm implemented in MaxEnt v.3.4.1 (Phillips \& al. 2006) was used to determine the potential distribution for Opuntia aurantiaca. For modelling we used all the occurrences detected (see ESF1, Appendix); for some of them, more than one unique geographic coordinate has been considered to cover the total area where the species is found in that locality (e.g. Vilajuiga and Pau populations). As these occurrences were recent and accurate, the resolution used was 30 arc-sec (i.e. ca. $1 \mathrm{~km}$ ). The 19 bioclimatic variables and altitude, also at 30 arc-sec resolution, were downloaded from the WorldClim website (www.worldclim.org; Hijmans \& al. 2005). The Human Footprint (HF) (Sanderson \& al. 2002) was also chosen because the establishment and spread of $O$. aurantiaca is related to human disturbance. A small set of eight relatively uncorrelated variables $(r<|0.8|)$ were selected (see ESF1, Text S1). Niche models have been developed for both current climatic conditions and different climate change scenarios for the year 2070. For the present conditions, we have built two models, one including the variable HF and the other excluding it. For the future, we used the three widely used general circulation models in two different representative concentration pathways (RCPs), RCP 2.6 and RCP 8.5 (see ESF1, Text S1). Details on the methods of replication, model performance assessment, thresholding, map representation, and calculations on gained/lost areas are in ESF1, Text S1.

\section{Results and Discussion}

\section{Current distribution range of Opuntia aurantiaca in the Iberian Peninsula}

There are no reports of the presence of Opuntia aurantiaca in the Iberian Peninsula (and in the whole of Europe) until recently. The first time that it was observed with certainty 
(although mistakenly reported as O. pestifer Britton \& Rose) was in 2002 in the limestone walls around Navajas (Vázquez 2009; see also ESF1, Appendix), a small village in the province of Castelló, about $30 \mathrm{~km}$ from the coastline, in the Valencian Community. The second observation of this cactus was not until 2008, from Tivenys, near the Ebro River, in southern Catalonia. However, the number of reports since 2010 quickly increased and, up to date, 36 occurrences have been recorded (ESF1, Appendix), distributed in five Spanish provinces along the Mediterranean coast: Girona, Barcelona and Tarragona of Catalonia, and Castelló and València of the Valencian Community (ESF1, Fig. S2). The largest concentrations of occurrences (and, thus, the potential spread foci) are southern Castelló/northern València, southern Tarragona, and central Barcelona provinces; however, the northernmost locations are particularly worrisome, since these are the largest and the invasion seems to be progressing faster there (see below).

Most reports of $O$. aurantiaca till recently seem to correspond to small populations of a few individuals (typically, less than 50) occupying a few square meters, perhaps escaping from nearby private gardens. For example, in Navajas (the first report of $O$. aurantiaca in Europe, in 2002), just a dozen individuals were observed in a small area of a few square meters (J. R. Vázquez, pers. comm.), whereas in Tivenys (the second report, dating from 2008 ) the population was not much larger (around or slightly more than 20 individuals in an area of about $25 \mathrm{~m}^{2}$; S. Pyke, pers. comm.). Other localities observed at the beginning or middle 2010s are also of relatively small size, although with some exceptions (ESF1, Appendix). However, according to the most recent observations (from 2017 onwards), both own and from colleagues, most populations seem to be getting bigger in number of individuals and thus affecting much larger areas. These observations are coinciding with the putative spread of the cactus towards the north (province of Girona and parts of the province of Barcelona; ESF1, Fig. S2). For example, in Vilajuilga there are over 2 ha of land covered by $O$. aurantiaca (Fàbregas 2018), and the species has spread to a nearby village (Pau; ESF1, Appendix). Only a close monitoring of populations, however, could allow to test whether this purported recent expansion is actually occurring. Fortunately, $O$. aurantiaca is not a popular garden plant here, since we have not detected any shop selling it, which may guarantee a certain level of containment.

\section{Present and future potential distribution of Opuntia aurantiaca}

The ENM models have been built with occurrence data for 41 cells of 30 arc-sec resolution, a size that is enough for getting reliable results and avoid the need for using jackknife validation (an approach that may produce overoptimistic estimates of predictive power with sample sizes $>25$; Pearson \& al. 2007). Indeed, both AUC and TSS values indicated that the models performed well (AUC values $>0.990$; TSS values $>0.887$; ESF1, Table S1). In all models the variables that contributed the most are bio8 (average temperature of the wettest quarter) and altitude (ESF1, Table S1). Given that the low cold-tolerance is one of the most limiting factors of succulent species with a CAM (Crassulacean Acid Metabolism) photosynthetic strategy (Lüttge 2004), the absence of bio6 (minimum temperature of the coldest month) in the list of variables used for modeling may be surprising. For example, bio6 is the most important variable for the ENM in other succulent plants, such as Dendrocereus nudiflorus (Engelm. ex Sauvalle) Britton \& Rose (Cactaceae; Barrios \& Mancina 2017) and Kalanchoe $\times$ houghtonii D. B. Ward 
(Crassulaceae; Herrando-Moraira \& al. 2020). However, bio6 is actually represented in our models for Opuntia aurantiaca by the variable altitude, as they were highly correlated in our preliminary models $(r=-0.85)$, and we selected the latter because of its higher weight in the model and its better (i.e. more easy to interpret) response curve (ESF1, Figs. S3-S5). In addition, bio11 (mean temperature of the coldest quarter), a variable highly correlated $(r=0.98)$ with bio6, is also an important variable in our model (ESF1, Table S1).

The most explanatory variable in all models for $O$. aurantiaca is bio8, the average temperature of the wettest quarter. The response curve of this variable is asymptotic, with the probability of occurrence starting to increase at about $2-3^{\circ} \mathrm{C}$ and reaching the maximum values at about $16-17^{\circ} \mathrm{C}$ (ESF1, Fig. S6). In other words, the species would not be capable to grow in too cold places when the rain season occurs, probably reflecting the climate of the area where the species presumably originated, eastern Argentina (mostly in the Entre Ríos Province) and southwestern Uruguay (Moran \& al. 1976); in this region, the rainy season coincides with the austral summer (Inumet 2020; SMN 2020). These climatic constraints for $O$. aurantiaca could be easily explained by the lack of freezing tolerance of most cacti and succulent plants in general. Although some cacti [such as O. humifusa (Raf.) Raf.] have the sugar-mediated osmoregulation mechanism to control freeze dehydration (for example, this allows $O$. streptacantha Lem. to tolerate temperatures as low as $-24^{\circ} \mathrm{C}$; Goldstein \& Nobel 1994), this does not seem to be the case for O. aurantiaca; neither the native areas nor invasive ones include cold-weather areas. Such effects of cellular freeze dehydration could be enhanced under a high-precipitation regime, as it produces the lowering of intracellular osmotic pressure, thus promoting the diffusion of intracellular water into the apoplastic spaces where ice crystals are formed. Certainly, the negative effects of freeze dehydration are well-known in succulents gardening- "weather that is most threatening to succulents is rain followed by frost" (Baldwin 2017). Interestingly, such effects were already noted in South Africa by Zimmermann \& van de Venter (1981) for O. aurantiaca: "The plant does not establish well in winter rainfall areas". In O. ficusindica, which also has the sugar-mediated osmoregulation mechanism (Goldstein \& Nobel 1991) but not as effective as in O. humifusa (O. ficus-indica cannot tolerate temperatures below $-10^{\circ} \mathrm{C}$ ), bio8 was also the most important variable for its niche model built for the Iberian Peninsula (Guillot \& al. 2015).

The maps depicting the suitable areas for $O$. aurantiaca at the present time do not show very large differences between them (Fig. 2), although the model incorporating the variable HF recovers somewhat smaller areas $\left(10.444 \mathrm{~km}^{2}\right.$ vs. $13.617 \mathrm{~km}^{2}$; Table 1$)$. The most inland areas - those with fewer human activities - have not been considered as suitable in the model with HF (e.g. the Ebro River basin), although a smaller area for models incorporating HF compared to models without HF has already been reported for the succulent $K . \times$ houghtonii (Herrando-Moraira \& al. 2020). Despite the fact that $O$. aurantiaca seems to be actively spreading in Catalonia and the Valencian Community, our maps of potential distribution for the present do not predict large expansions to other areas of the Iberian Peninsula (Fig. 2). Although the current occurrences are far to fill all of the predicted distribution, $O$. aurantiaca would hardly colonize regions outside the areas of typical Mediterranean climate (the Csa climate according to the Köppen-Geiger classification; http://koeppen-geiger.vu-wien.ac.at/) on the Mediterranean coast of the eastern part of the Iberian Peninsula (see also AEMET \& IM 2011). A similar potential distribution for the 


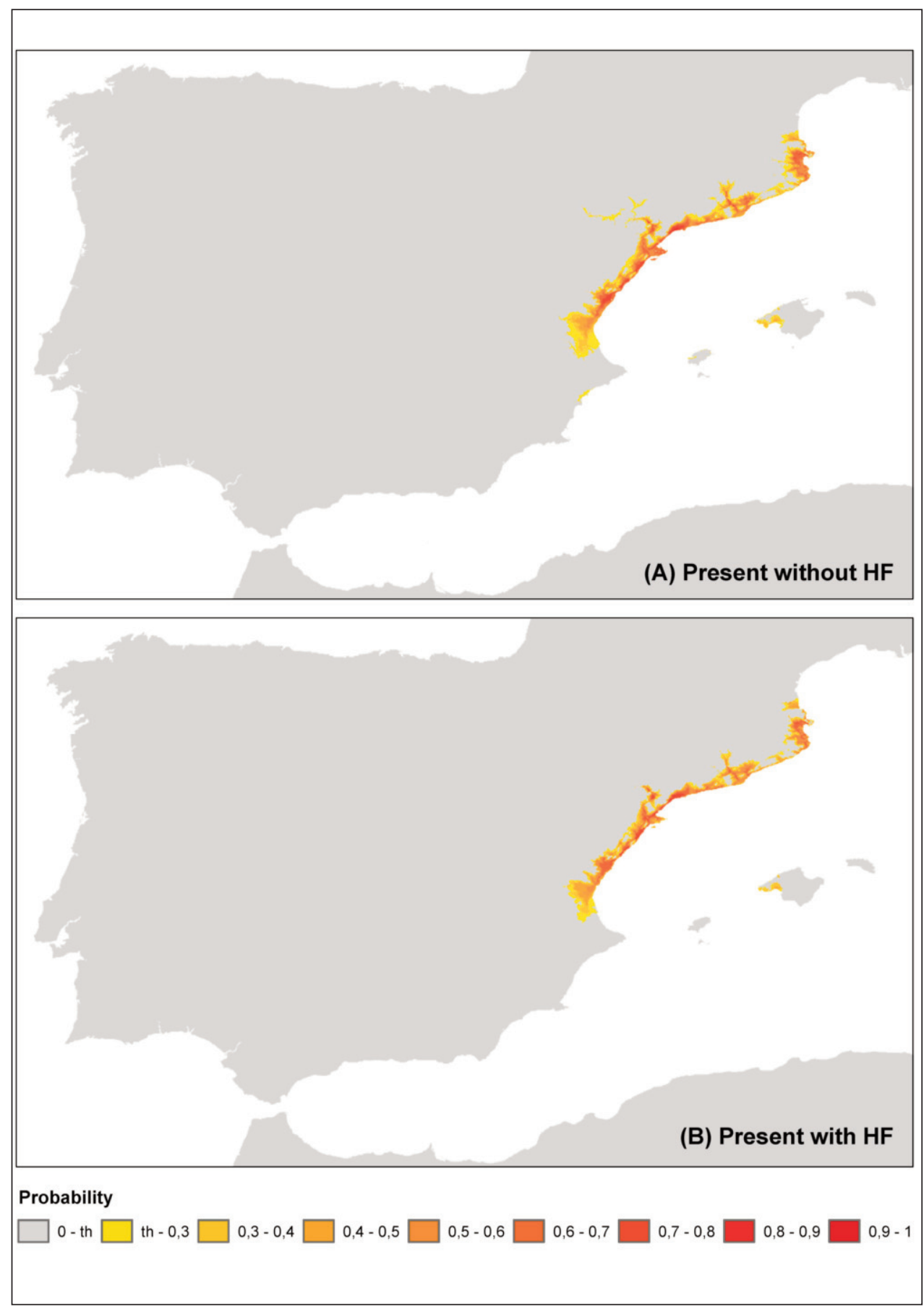

Fig. 2. Potential distribution areas of Opuntia aurantiaca in the Iberian Peninsula under present climatic conditions (A) not including Human Footprint (HF) or (B) including HF to perform the models. 
Table 1. Extension of suitable predicted areas of Opuntia aurantiaca for each model. The overlap area between present (without considering Human Footprint variable; HF) and respective future models, and the lost and gained area for future predictions with respect to present models are also presented.

\begin{tabular}{|c|c|c|c|c|c|}
\hline Model & $\begin{array}{l}\text { Predicted } \\
\text { area in } \\
\mathbf{k m}^{2}\end{array}$ & $\begin{array}{c}\text { Difference } \\
\text { with present } \\
\text { in } \mathbf{k m}^{2}(\%)\end{array}$ & $\begin{array}{c}\text { Overlap with } \\
\text { present in } \\
\mathbf{k m}^{2}\left(\%^{\mathrm{a}} ; \%^{\mathrm{b}}\right)\end{array}$ & $\begin{array}{l}\text { Lost area in } \\
\text { the future in } \\
\mathrm{km}^{2}(\%)\end{array}$ & $\begin{array}{c}\text { Gained area } \\
\text { in the future } \\
\text { in } \mathbf{k m}^{2}(\%)\end{array}$ \\
\hline $\begin{array}{l}\text { Present (without } \\
\text { HF) }\end{array}$ & 13,617 & - & - & - & - \\
\hline Present (with HF) & 10,444 & $\begin{array}{c}3,174 \\
(-23.31)\end{array}$ & $\begin{array}{c}10,434 \\
(76.62 ; 99.91)\end{array}$ & - & - \\
\hline $\begin{array}{l}\text { Future } 2070 \\
\text { CCSM (RCP 2.6) }\end{array}$ & 14,393 & $\begin{array}{c}775 \\
(+5.69)\end{array}$ & $\begin{array}{c}12,341 \\
(90.62 ; 85.74)\end{array}$ & $\begin{array}{l}1,277 \\
(9.38)\end{array}$ & $\begin{array}{c}2,052 \\
(15.07)\end{array}$ \\
\hline $\begin{array}{l}\text { Future } 2070 \\
\text { CCSM (RCP 8.5) }\end{array}$ & 16,620 & $\begin{array}{c}3,002 \\
(+22.04)\end{array}$ & $\begin{array}{c}10,468 \\
(76.87 ; 62.99)\end{array}$ & $\begin{array}{c}3,149 \\
(23.13)\end{array}$ & $\begin{array}{c}6,151 \\
(41.17)\end{array}$ \\
\hline $\begin{array}{l}\text { Future } 2070 \\
\text { GFDL (RCP 2.6) }\end{array}$ & 11,063 & $\begin{array}{c}2,555 \\
(-18.76)\end{array}$ & $\begin{array}{c}10,644 \\
(78.16 ; 96.22)\end{array}$ & $\begin{array}{l}2,974 \\
(21.84)\end{array}$ & $\begin{array}{c}419 \\
(3.07)\end{array}$ \\
\hline $\begin{array}{l}\text { Future } 2070 \\
\text { GFDL (RCP 8.5) }\end{array}$ & 14,798 & $\begin{array}{c}1,181 \\
(+8.67)\end{array}$ & $\begin{array}{c}7,958 \\
(58.43 ; 53.77)\end{array}$ & $\begin{array}{c}5,660 \\
(41.57)\end{array}$ & $\begin{array}{c}6,841 \\
(50.23)\end{array}$ \\
\hline $\begin{array}{l}\text { Future } 2070 \text { MPI } \\
\text { (RCP 2.6) }\end{array}$ & 17,117 & $\begin{array}{c}3,500 \\
(+25.70)\end{array}$ & $\begin{array}{c}12,375 \\
(90.87 ; 72.29)\end{array}$ & $\begin{array}{l}1,243 \\
(9.13)\end{array}$ & $\begin{array}{c}4,742 \\
(34.83)\end{array}$ \\
\hline $\begin{array}{l}\text { Future } 2070 \text { MPI } \\
(\text { RCP 8.5) }\end{array}$ & 6,069 & $\begin{array}{c}7,549 \\
(-55.43)\end{array}$ & $\begin{array}{c}4,810 \\
(35.32 ; 79.26)\end{array}$ & $\begin{array}{c}8,808 \\
(64.68)\end{array}$ & $\begin{array}{l}1,259 \\
(9.25)\end{array}$ \\
\hline
\end{tabular}

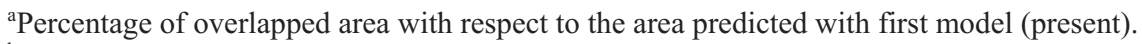

${ }^{b}$ Percentage of overlapped area with respect to the area predicted with each assayed model.

Iberian Peninsula was recovered for $O$. ficus-indica (with the exception that a small area in the Portuguese central coast also appeared as suitable; Guillot $\&$ al. 2015), which may indicate that the Mediterranean areas of central and southern Iberian Peninsula would not be entirely suitable for the establishment of Opuntia species. Among other factors, they are probably too dry in summer; for example, bio18, the precipitation of the warmest quarter (summer), should reach ca. $100 \mathrm{~mm}$ for the niche optimum of $O$. aurantiaca according to its response curve (ESF1, Fig. S6), a value of rainfall hardly occurring in the central and southern Iberian Peninsula (www.worldclim.org; AEMET \& IM 2011).

There is a high variability for the predicted range of $O$. aurantiaca in the Iberian Peninsula among the models for the different future climate scenarios, although, on average, there is a loss of $2.00 \%$ or $274 \mathrm{~km}^{2}$ with respect to present scenario data (Table 1). In general, when Figs. 2-3 are observed, no major changes in the predicted area can be observed between the models for the present and the models for the future, with perhaps the only exception of the MPI model under the RCP 8.5 scenario (with a 


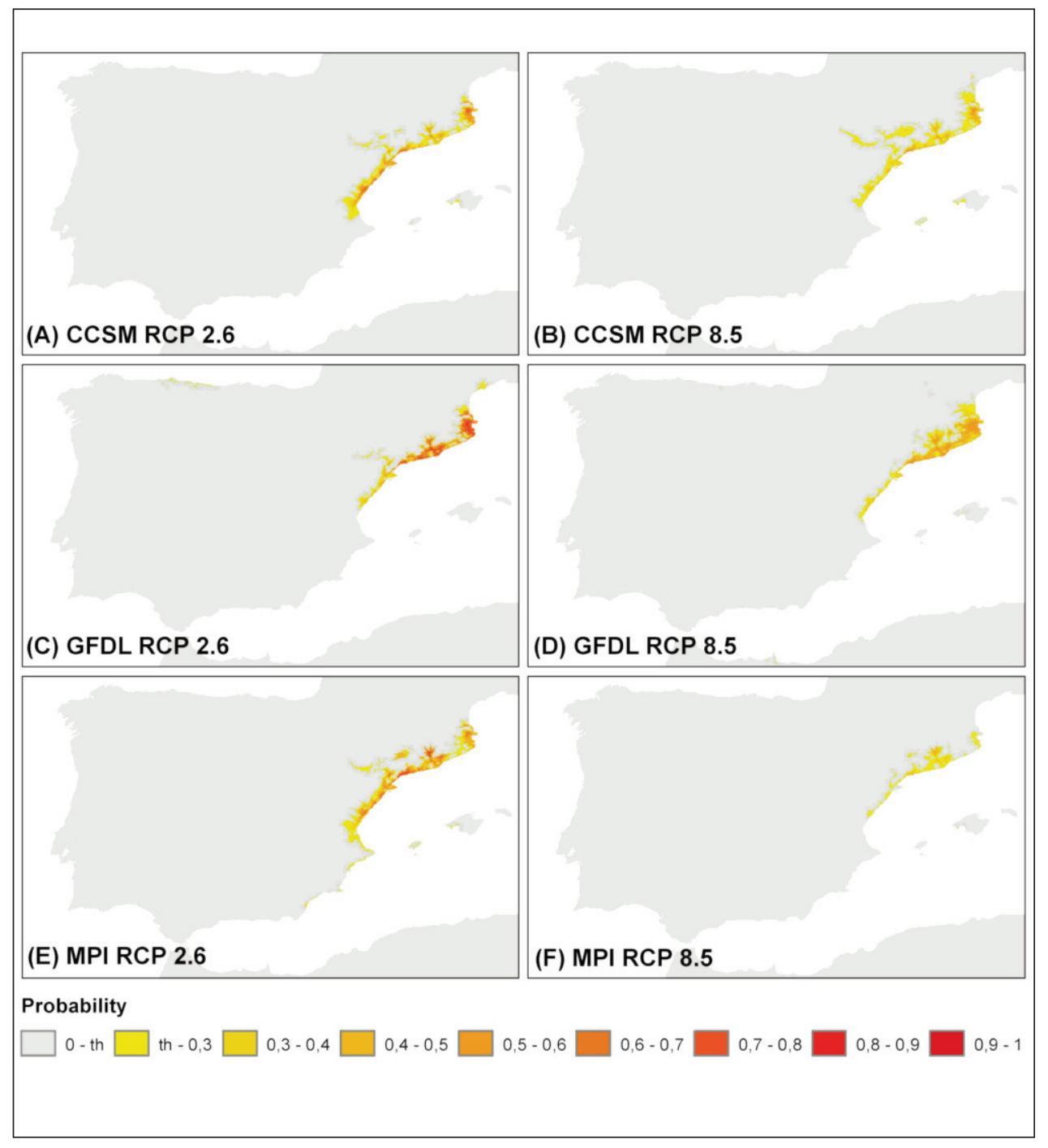

Fig. 3. Potential distribution areas of Opuntia aurantiaca in the Iberian Peninsula under future climatic conditions, using the CCSM model for (A) RCP 2.6 and (B) RCP 8.5, the GFDL model for (C) RCP 2.6 and (D) RCP 8.5, and the MPI model for (E) RCP 2.6 and (F) RCP 8.5. The RCP 2.6 scenario represents an increase of $0.3-1.7^{\circ} \mathrm{C}$ for ca. $2081-2100$, whereas RCP 8.5 forecasts an increase of $2.6-$ $4.8^{\circ} \mathrm{C}$ for the same period (see ESF1, Text S1).

considerable loss of suitable area, of up to $55 \%$; Table 1). Such variability between models for the year 2070 for $O$. aurantiaca is not an unexpected result given that the uncertainty of predicting suitable areas using climate forecasts and not real data (e.g. Guevara \& al. 2019) is added to the fact that we are only focusing on a part of the 
species' world range. For example, in the succulent Kalanchoe $\times$ houghtonii all global models show a reduction in the potential distribution area for the year 2070 with no very large differences between them (mean $=33.5 \% \pm 17.0 \%$ ), but if we "zoom in" to the Iberian Peninsula (see Fig. 8 in Herrando-Moraira \& al. 2020) the differences become very pronounced. It should be taken into account, however, the limitation of our niche model due the use of only Iberian occurrences; one may suppose that the suitable area in the Iberian Peninsula would be larger if all world occurrences are used for modeling, as native occurrences or other introduced areas occurrences could grow under different climatic conditions than the Iberian ones. Although beyond the scope of this study, it would be advisable, thus, to model the niche with all occurrences of $O$. aurantiaca.

\section{Acknowledgements}

This work received financial support from the "Proyecto Intramural Especial, PIE" (grant no. 201630I024) from the CSIC (Spain) and from the "Ajuts a Grups de Recerca Consolidats" (grants nos. 2014-SGR514-GREB and 2017-SGR1116) from the Generalitat de Catalunya (Spain). We are also grateful to the Generalitat Valenciana's environmental keeper Pascual San Lázaro, for her transfer of captions and field collaboration.

\section{References}

AEMET \& IM (Agencia Estatal de Meteorología/Instituto de Meteorologia) 2011: Atlas climático ibérico. Temperatura del aire y precipitación (1971-2000). - Madrid \& Lisboa.

Anderson, E. F. 2001: The cactus family. - Portland.

Archibald, E. E. A. 1939: The development of the ovule and seed of jointed cactus (Opuntia aurantiaca Lindley). - S. Afr. J. Sci. 36: 195-211.

Arnold, T. H. 1977: The origin and relationships of Opuntia aurantiaca Lindley. - Proc. Natl. Weeds Conf. S. Afr. 2: 269-286.

Aymerich, P. \& Sáez, L. 2019: Checklist of the vascular alien flora of Catalonia (northeastern Iberian Peninsula, Spain). - Medit. Bot. 40: 215-242. https://doi.org/10.5209/mbot.63608

Baldwin, D. L. 2017: Designing with succulents. - Portland.

Barrios, D. \& Mancina, C. A. 2017: Dendrocereus nudiflorus (Cactaceae): pasado, presente y futuro de un anacronismo en peligro de extinción según modelos de nicho climático. - Revista Jard. Bot. Nac. Univ. Habana 38: 119-132.

Berthet, P. 1990: Opuntia Miller. Pp. $62-70$ in: Castroviejo, S., López González, G., Muñoz Garmendia, F., Paiva, J. \& Villar, L. (eds), Flora ibérica, 2. - Madrid.

Burguera, C., Gómez-Bellver, C., Guillot, D., Ibáñez, N., López-Pujol, J. \& Nualart, N. 2019: Introduction of the genus Agave in the Iberian Peninsula. Pp. 1-26 in: Engman, E. (ed), Agave: characterization, analysis and uses. - New York.

CABI (CAB International) 2020: Opuntia aurantiaca in Invasive Species Compendium. CAB International. - Published at: https://www.cabi.org/ISC [Last Accessed 26/03/2020].

Casasayas, T. 1989: La flora al·lòctona de Catalunya. Catàleg raonat de les plantes vasculars exòtiques que creixen sense cultiu al NE de la Península Ibèrica. PhD thesis. - Barcelona.

Chinnock, R. J. 2015: Feral opuntioid cacti in Australia: Part I. Cylindrical-stemmed genera: Austrocylindropuntia, Cylindropuntia and Corynopuntia. - J. Adelaide Bot. Gard. 3: 1-69. 
DAWE (Department of the Agriculture, Water and the Environment, Australian Goverment): 2020. Opuntia aurantiaca in Weeds of Australia. - Published at: https://www. environment.gov.au/cgi-bin/biodiversity/invasive/weeds/weeddetails.pl? taxon_id=2327. [Last accessed 02/04/2020]

Fàbregas, E. 2018: Estat actual del poblament del cactus exòtic Opuntia aurantiaca al municipi de Vilajuïga. Proposta d'accions per al seu control i contenció. Galanthus. - Celrà.

GBIF (Global Biodiversity Information Facility) 2020: Opuntia aurantiaca in Global Biodiversity Information Facility. - https://doi.org/10.15468/dl.wruxo7

Generalitat Valenciana 2009: Decreto 213/2009, de 20 de noviembre, del Consell, por el que se aprueban medidas para el control de especies exóticas invasoras en la Comunitat Valenciana. - Diari Oficial de la Comunitat Valenciana 6151: 42326-42332.

Goldstein, G. \& Nobel, P. S. 1991: Changes in osmotic pressure and mucilage during low-temperature acclimation of Opuntia ficus-indica. - Pl. Physiol. 97: 954-961. https://doi.org/10.1104/pp.97.3.954

- 1994: Water relations and low temperature acclimation for cactus species varying in freezing tolerance. - Pl. Physiol. 104: 675-681. https://doi.org/10.1104/pp.104.2.675

Guàrdia, L. 2016: On the presence of Opuntia aurantiaca (Opuntioideae, Cactaceae) in Catalonia (northeastern Iberian Peninsula). - Orsis 30: 3-9. https://doi.org/10.5565/rev/orsis.31

Guardiola, M. \& Petit, A. 2020: Aportacions a la flora al·lòctona de la serralada Litoral central catalana i territoris propers. - Butll. Inst. Catalana Hist. Nat. 84: 35-49.

Guevara, L., Morrone, J. J., León-Paniagua, L. 2019: Spatial variability in species' potential distributions during the Last Glacial Maximum under different Global Circulation Models: Relevance in evolutionary biology. - J. Zool. Syst. Evol. Res. 57: 113-126. https://doi.org/10.1111/jzs.12238

Guillot, D., López-Pujol, J., Laguna, E., Silva, V. \& Puche, C. 2015: Un nuevo cultivar de Luther Burbank presente en la flora alóctona de la Península Ibérica, Opuntia ficus-indica 'Vertex'. Bouteloua 20: 124-143.

Herrando-Moraira, S., Vitales, D., Nualart, N., Gómez-Bellver, C., Ibáñez, N., Massó, S., CachónFerrero, P., González-Gutiérrez, P., Guillot, D., Herrera, I., Shaw, D., Stinca, A., Wang, Z., \& López-Pujol, J. 2020: Global distribution patterns and niche modelling of the invasive Kalanchoe $\times$ houghtonii (Crassulaceae). $\quad-\quad$ Sci. Rep. 10: 3143. https://doi.org/10.1038/s41598-020-60079-2

Hijmans, R.E., Cameron, S. E., Parra, J. L., Jones, P. G., Jarvis, A. 2005: Very high resolution interpolated climate surfaces for global land areas. - Int. J. Climatol. 25: 1965-1978. https:// doi.org/10.1002/joc. 1276

Hosking, J. R. 2002: Opuntia spp. Pp. 431-436 in: Julien, M. H., McFadyen, R. E. C., Cullen, J. M. (eds), Biological control of weeds in Australia. - Melbourne.

Inumet (Instituto Uruguayo de Meterorología) 2020: Estadísticas meteorológicas. - Published at: https://www.inumet.gub.uy/clima/estadisticas-climatologicas [Last accessed 29/03/2020].

Lüttge, U. 2004: Ecophysiology of Crassulacean Acid Metabolism (CAM). - Ann. Bot. 93: 629-652. https://doi.org/10.1093/aob/mch087

Mack, R. N., Simberloff, D., Lonsdale, W. M., Evans, H., Clout, M. \& Bazzaz, F. A. 2000: Biotic invasions: causes, epidemiology, global consequences, and control. - Ecol. Appl. 10: 689-710. https://doi.org/10.1890/1051-0761(2000)010[0689:BICEGC]2.0.CO;2

Moore, D. M. 1968. Opuntia Miller. Pp. 118-300 in: Tutin, T. G., Heywood, V. H., Burges, N. A., Moore, D. M., Valentine, D. H., Walters, S. M. \& Webb, D. A. (eds), Flora Europaea 2. - Cambridge.

Moran, V. C. \& Annecke, D. P. 1979: Critical reviews of biological pest control in South Africa. 3. The jointed cactus, Opuntia aurantiaca Lindley. - J. Entomol. Soc. S. Afr. 42: 299-329. https://doi.org/10.1016/0167-8809(91)90136-L 
— \& Zimmermann, H. G. 1991: Biological control of jointed cactus, Opuntia aurantiaca (Cactaceae), in South Africa. - Agric. Ecosyst. Environ. 37(1-3): 5-27. https://doi.org/10.1016/0167-8809(91)90136-L

_, — \& Annecke, D. P. 1976: The identity and distribution of Opuntia aurantiaca Lindley. - Taxon 25: 281-287. https://doi.org/10.2307/1219455

Novoa, A., Le Roux, J. J., Robertson, M. P., Wilson, J. R. U. \& Richardson, D. M. 2015: Introduced and invasive cactus species: a global review - AoB Plants 7: plu078. https://doi.org/10.1093/aobpla/plu078

—, Brundu, G., Day, M. D., Deltoro, V., Essl, F., Foxcroft, L. C., Fried, G., Kaplan, H., Kumschick, S., Lloyd, S., Marchante, E., Marchante, H., Paterson, I. D., Pyšek, P., Richardson, D. M., Witt, A., Zimmermann, H. G. \& Wilson, J. R. U. 2019: Global actions for managing cactus invasions. - Plants 8: 421. https://doi.org/10.3390/plants8100421

Ochoa, M. J. \& Barbera, G. 2017: History and economic and agro-ecological importance. Pp. 1-11 in: Inglese P, Mondragon C, Nefzaoui A, Sáenz C. (eds), Crop ecology, cultivation and uses of cactus pear. - Rome.

Pearson, R. G., Raxworthy, C. J., Nakamura, M. \& Peterson, A. T. 2007: Predicting species distributions from small numbers of occurrence records: a test case using cryptic geckos in Madagascar. - J. Biogeog. 34: 102-117. https://doi.org/10.1111/j.1365-2699.2006.01594.x

Phillips, S. J., Anderson, R. P. \& Schapire, R.E. 2006: Maximum entropy modeling of species geographic distributions. $\quad-\quad$ Ecol. Model. 190: 231-259. https://doi.org/10.1016/j.ecolmodel.2005.03.026

Pozueta, J. 2015: Rasgos urbanísticos del crecimiento residencial asociado a la burbuja inmobiliaria, 1995-2006. - Cuadernos de Investigación Urbanística 100: 87-94. https://dx.doi.org/10.20868/ciur.2015.100.3170

Sanderson, E. W., Jaiteh, M., Levy, M. A., Redford, K. H., Wannebo, A. \& Woolmer, G. 2002: The human footprint and the last of the wild. - BioScience 52: 891-904. https://doi.org/10.1641/0006-3568(2002)052[0891:THFATL]2.0.CO;2

Sanz-Elorza, M., Dana, E. D. \& Sobrino, E. 2001: Listado de plantas alóctonas invasoras reales y potenciales en España. - Lazaroa 22: 121-131.

—, — \& - 2004: Sobre la presencia de cactáceas naturalizadas en la costa meridional de Cataluña. - Anales. Jard. Bot. Madrid 61: 27-33. https://doi.org/10.3989/ajbm.2004.v61.i1.63

SMN (Servicio Meteorológico Nacional). 2020: Estadísticas climáticas. - Published at: https://www.smn.gob.ar/estadisticas [Last accessed 29/03/2020].

van de Venter, H. A., Hosten, L., Lubke, R. A., \& Palmer, A. R. 1984: Morphology of Opuntia aurantiaca (jointed cactus) biotypes and its close relatives, $O$. discolor and $O$. salmiana (Cactaceae). - S. Afr. J. Bot. 3: 331-339. https://doi.org/10.1016/s0022-4618(16)30021-3

Vázquez, J. R. 2009: Contribución al conocimiento de la flora del Alto Palancia (Castellón). - Fl. Montiberica 42: 83-85.

— \& Albiach, X. 2016: Adiciones y correcciones a la flora alóctona de la provincia de Castellón: Cactáceas. - Bouteloua 24: 3-10.

Verloove, F. \& Guiggi, A. 2019: Further records of cacti (Cactaceae) from Tarragona province (Catalonia), Spain. - Haseltonia 26: 23-35. https://doi.org/10.2985/026.026.0104

Walters, M., Figueiredo, E., Crouch N. R., Winter, P. J. D., Smith, G.F., Zimmermann, H.G. \& Mashope, B. K. 2011: Naturalised and invasive succulents of southern Africa. ABC Taxa 11. - Brussels.

Yuasa, H., Shimizu, H., Kashiwai, S. \& Kondo, N. 1973: Chromosome numbers and their bearing on the geographic distribution in the subfamily Opuntioideae (Cactaceae). - Rep. Inst. Breed. Res., Tokyo Univ. Agric. 4: 1-10. 
Zimmermann, H. G. \& van de Venter, H. A. 1981: Jointed cactus. Weed Series, Division of Agricultural Information A.1. - Pretoria.

Addresses of the authors:

Carlos Gómez-Bellver ${ }^{1}$, Emilio Laguna ${ }^{2}$, Agustí Agut ${ }^{3}$, Gabriel Ballester ${ }^{2}$, Salvador Cardero $^{4}$, Vicente Deltoro ${ }^{5}$, Enric Fàbregas ${ }^{6}$, Simón Fos ${ }^{5}$, Simón Francisco ${ }^{7}$, Daniel Guillot $^{8}$, Josep E. Oltra ${ }^{5}$, David Pérez-Prieto ${ }^{9}$, Patricia Pérez Rovira ${ }^{5}$, Romà Senar ${ }^{10}$, Neus Ibáñez ${ }^{9}$, Sonia Herrando-Moraira ${ }^{9}$, Neus Nualart ${ }^{9}$ \& Jordi López-Pujol ${ }^{9}$

${ }^{1}$ Unit of Botany and Mycology, Department of Evolutionary Biology, Ecology and Environmental Sciences, Faculty of Biology, University of Barcelona, Avda. Diagonal, 643 - 08028 Barcelona, Spain. Email: cgomezbellver@gmail.com

${ }^{2}$ Generalitat Valenciana, Servicio de Vida Silvestre - CIEF (Centro para la Investigación y Experimentación Forestal), Avda. Comarques del País Valencià, 114 - 46930 Quart de Poblet, València, Spain.

${ }^{3}$ Jardín Botánico de Olarizu, Casa de la Dehesa de Olarizu - 01006 Vitoria-Gasteiz, Alaba/Araba, Spain.

${ }^{4}$ Avda. Josep Tarradellas, $1484^{\circ}$ B - 43870 Amposta, Tarragona, Spain

${ }^{5}$ VAERSA, Generalitat Valenciana, Avda. Corts Valencianes, 20 - 46015 València, Spain.

${ }^{6}$ Galanthus, Ctra Juià, 46 - 17460 Celrà, Girona, Spain

${ }^{7}$ c. Sant Antoni, 26 - 12190 Borriol, Castelló, Spain.

${ }^{8}$ c. La Pobleta, 7 - 46118 Serra, València, Spain.

${ }^{9}$ Botanic Institute of Barcelona (IBB, CSIC-Ajuntament de Barcelona), Passeig del Migdia, s/n - 08038 Barcelona, Spain.

${ }^{10}$ c. César Cataldo, 13 - 12580 Benicarló, Castelló, Spain. 